\title{
PERAN MOTIVASI KERJA DAN KEPUASAN KERJA DALAM MEMEDIASI PENGARUH BUDAYA ORGANISASI TERHADAP KINERJA KARYAWAN PADA PT BANK ACEH SYARIAH CABANG BIREUEN
}

\author{
Em Yusuf Iis ${ }^{1 *}$ Yanita $^{2}$ \\ 1. Program Pascasarjana Ilmu Manajemen FEB Universitas Malikussaleh ${ }^{2}$ Fakultas Ekonomi dan Bisnis \\ Universitas Malikussaleh \\ *Email Corespondent : emyusuf@unimal.ac.id
}

\begin{abstract}
This study examines the influence of organizational culture on employee performance and examines the mediating effect of work motivation and job satisfaction variables. The research sample was 114 employees at the Aceh Sharia Bank Bireuen Branch. The analytical tool used is path analysis using the SEM method (structural equation modeling) using Amos. The results showed that each variable of organizational culture, work motivation and job satisfaction has a positive and significant effect on performance, and work motivation mediates exogenous variables with endogenous variables partially mediating. Job satisfaction variable, on the other hand, becomes a very good intermediary (full mediation) between exogenous and endogenous variables

Keywords : Organizational Culture, Work Motivation, Job Satisfaction, and Employee Performance
\end{abstract}

Abstrak: Penelitian ini menguji pengaruh budaya organisasi terhadap kinerja karyawan dan menguji pengaruh mediasi motivasi kerja dan variabel kepuasan kerja. Sampel penelitian adalah 114 karyawan pada Bank Syariah Aceh Cabang Bireuen. Alat analisis yang digunakan adalah analisis jalur dengan metode SEM (pemodelan persamaan struktural) menggunakan Amos. Hasil penelitian menunjukkan bahwa masing-masing variabel budaya organisasi, motivasi kerja dan dan kepuasan kerja berpengaruh positif dan signifikan terhadap kinerja, dan motivasi kerja memediasi variabel eksogen dengan variabel endogen yang secara parsial mediasi. Variabel kepuasan kerja, di sisi lain, menjadi perantara yang sangat baik (full mediasi) antara variabel eksogen dan variabel endogen

Keywords : Budaya Organisasi, Motivasi Kerja, Kepuasan Kerja, dan Kinerja Karyawan. 


\section{PENDAHULUAN}

Perkembangan teknologi yang pesat membawa perubahan yang tidak dapat kita cegah dalam kehidupan. Orang-orang yang merupakan elemen pelaksana harus dapat melacak semua perubahan ini. Sumber daya manusia merupakan elemen yang sangat penting dalam sebuah perusahaan. Tanpa peran manusia, organisasi tidak akan berjalan mulus, meski ada beberapa faktor yang dibutuhkan. Sumber daya manusia merupakan syarat dasar untuk menjalankan semua aktivitas yang ada di berbagai area organisasi di dalam perusahaan. Kinerja pada dasarnya adalah apa yang dilakukan atau tidak dilakukan karyawan. Kinerja mempengaruhi seberapa banyak mereka berkontribusi pada organisasi, termasuk jumlah output, kualitas output, durasi output, ketersediaan mereka di tempat kerja, dan sikap kolaboratif mereka (Mathis, 2000).

Manajemen sumber daya manusia diperlukan untuk mengembangkan dan mewujudkan sumber daya yang berkualitas dan berkinerja tinggi (Medin et al., 2013). Jika kita menganggap organisasi baru sebagai salah satu inovasi terpenting abad ini, keberhasilan organisasi bergantung pada kombinasi penggunaan sumber daya yang efisien dan strategi organisasi yang efisien (Alami et al., 2015). Beberapa faktor yang dapat mempengaruhi kinerja karyawan antara lain kepuasan kerja dan disiplin kerja (Sari \& Hadijah, 2016). Kepuasan kerja memainkan peran penting dalam kehidupan manusia karena dapat mempengaruhi individu dan organisasi (Stanton et al., 2002).

Agar kinerja karyawan selalu konsisten setiap saat, setidaknya organisasi selalu memperhatikan lingkungan kerja di sekitar karyawan dan hal ini dapat mempengaruhi kemampuan seseorang dalam melaksanakan tugas-tugas seperti motivasi. Salah satu teori motivasi tentang kebutuhan individu adalah teori Maslow. Maslow berpendapat bahwa seseorang bekerja karena dorongan hatinya untuk memenuhi berbagai kebutuhan. Hirarki kebutuhan Maslow dalam Mathis dan Jackson (2011) membagi kebutuhan menjadi lima kategori yang naik dalam urutan tertentu. Sampai lebih banyak kebutuhan dasar terpenuhi, seseorang tidak akan berusaha memenuhi kebutuhan yang lebih tinggi. Oleh karena itu apabila kebutuhan atau motivasi dapat terpenuhi (tinggi) maka kinerja pegawai juga tinggi (Miswan, 2010).

Hal tersebut dapat dilakukan dengan berbagai cara sebagai pengendali seluruh aktivitas organisasi untuk meningkatkan kinerja karyawan, salah satunya adalah motivasi kerja. Karena motivasi kerja dapat mempengaruhi kinerja karyawan. Daft (2003) mengacu pada motivasi, dorongan baik dari dalam maupun luar seseorang yang membangkitkan antusiasme dan desakan untuk melakukan tindakan tertentu. Motivasi kerja merupakan kondisi yang efektif untuk menghasilkan, mengarahkan dan memelihara perilaku yang berkaitan dengan lingkungan kerja (McCormick, 1985 dalam Wardani, 2014). Dengan motivasi yang tepat maka karyawan akan termotivasi untuk melakukan yang terbaik dalam melaksanakan tugas, bersemangat dan tidak menunda waktu dalam melaksanakan tugas.

Kepuasan kerja tidak kalah pentingnya, kepuasan kerja adalah memenuhi semua kebutuhan karyawan saat melaksanakan tugas pada waktu-waktu tertentu (Usman, 2011). Kepuasan kerja merupakan masalah penting karena berkaitan dengan kesejahteraan fisik dan mental karyawan dan dampaknya terhadap perilaku terkait pekerjaan seperti produktivitas, ketidakhadiran atau pergantian karyawan. Pekerjaan merupakan aspek penting dalam kehidupan masyarakat, dan sebagian besar karyawan menghabiskan sebagian besar hidupnya di tempat kerja. Memahami faktorfaktor yang mempengaruhi kepuasan kerja berkaitan dengan peningkatan kesejahteraan banyak orang (Oshagbemi, 1999). Menurut Hanaysha dan Tahir (2016), organisasi harus berinvestasi dalam mengembangkan program atau aktivitas yang dapat mempengaruhi kepuasan kerja karyawan, diyakini bahwa kinerja akan meningkat dalam jangka panjang melalui tingkat kepuasan kerja yang lebih tinggi.

Menurut Robbins (2006), faktor-faktor yang digunakan untuk meningkatkan kepuasan kerja antara lain motivasi dan kepuasan kerja. Kepuasan kerja sebagai hasil pemikiran dan tenaga untuk pekerjaannya dapat dilihat, dihitung, tetapi dalam banyak kasus hasil pemikiran dan tenaga manusia tidak dapat dilihat, ide pemecahan masalah, dan inovasi. Mungkin juga penemuan produk atau layanan baru, dan prosedur kerja yang lebih efisien.Perdebatan kepuasan kerja tidak lepas dari kenyataan bahwa kepuasan kerja dapat tercapai jika semua harapan terpenuhi saat menjalankan tugasnya. Menurut Nimalathasan (2009), kepuasan kerja berkaitan dengan harapan karyawan dari atasan, rekan kerja dan pekerjaan itu sendiri. Kepuasan kerja akan menjadi buruk jika karyawan di tempat kerja tidak puas dengan apa yang mereka harapkan, seperti peluang promosi yang adil, penghasilan yang baik, rekan kerja dan atasan yang baik, dan pekerjaan itu sendiri.

Ketidakpuasan mengakibatkan penarikan diri atau perilaku agresif, kesalahan yang disengaja, teguran, 
dll. Hal tersebut dapat mengakibatkan, yang tentunya dapat berdampak pada penurunan kinerja karyawan dan pada akhirnya membahayakan organisasi. Luthans (2006) menyatakan bahwa terdapat lima faktor yang mempengaruhi kepuasan kerja yaitu pendapatan, rekan kerja, peluang berkembang, pekerjaan itu sendiri, dan supervisor. Tobing (2009) dalam penelitiannya menyatakan bahwa kepuasan kerja berpengaruh positif dan signifikan terhadap kinerja karyawan. Sebaliknya, Packard dan Motowidlo (1987) dalam Kristianto (2012) menyatakan bahwa kepuasan kerja tidak berhubungan dengan kinerja karyawan.

Selain budaya organisasi juga perlu diperhatikan. Budaya organisasi pada dasarnya merupakan kebiasaan atau ritual yang diyakini dan dipraktekkan oleh seluruh anggota organisasi. Budaya mencerminkan apa yang dilakukan, bukan apa yang akan terjadi (Uha, 2013). Budaya organisasi memberikan ciri atau identitas pada suatu perusahaan atau organisasi dan memisahkan organisasi dari organisasi lain. Bank Syariah Aceh memiliki budaya kerja Islami, Aceh sendiri direkomendasikan oleh pemerintah pusat untuk memualafkan semua bank konvensional menjadi bank syariah karena masyarakatnya sangat taat dengan syariat Islam. Bank Aceh Syariah sendiri memiliki budaya kerja yaitu: Integritas, Silaturahmi, Loyalitas Nasabah, Amanah, Madani dan Ikhlas (ISLAMI). Budaya kerja ini diimplementasikan pada perusahaan dari generasi ke generasi yang mengelola Bank Aceh Syariah. Salah satunya pada Bank Aceh Syariah menerapkan nilai-nilai budaya kerja "ISLAMI" yang terdiri dari beberapa yaitu: (1) Integritas, yaitu menjalankan tugas dengan penuh tanggung jawab, jujur, berkomitmen dan konsisten. (2) Silaturahmi, yaitu membangun hubungan baik dengan kemitraan dengan nasabah serta stakeholder. (3) Loyalitas, yaitu memberikan produk dan layanan yang terbaik bagi nasabah. (4) Amanah, yaitu membangun sikap untuk menepati dan memenuhi janji kepada nasabah. (5) Madani, yaitu menciptakan dan membangun kemajuan bank secara terus menerus. (6) Ikhlas, yaitu menciptakan dan memebentuk sikap yang tulus dalam bekerja dan pengabdian.

Fenomena kinerja karyawan pada Bank Aceh Syariah Cabang Bireuen mencerminkan bahwa penurunan tersebut disebabkan oleh kualitas kerja karyawan, seperti penerapan pembiayaan untuk mendukung pemberdayaan ekonomi masyarakat di wilayah Bireuen. itu sering berulang-ulang. Selain itu, jumlah pekerja dalam pembiayaan mikro syariah tidak meningkat dalam beberapa bulan terakhir, karena kinerja karyawan yang rendah selama ini. Selain itu, masih rendahnya kreativitas karyawan dalam pelaksanaan komunikasi antara karyawan dengan pimpinan, sehingga usaha yang belum selesai berjalan semestinya. Namun, mereka memiliki keterampilan yang lebih siap dan andal dalam hal kemampuan bekerja. Masalah ini tentunya dipengaruhi oleh faktor kinerja yang negatif sehingga kinerja pegawai tidak meningkat.

Pada Bank Aceh Syariah Cabang Bireuen, kepuasan kerja karyawan belum dapat maksimal, hal ini terlihat dari rendahnya tingkat keintiman emosional rekan kerja yang masing-masing karyawan cenderung individualis daripada kooperatif, serta tidak adanya hubungan yang harmonis antara karyawan dengan atasannya. Kurang dari separuh karyawan top juga bisa menjadi masalah karena alasan kebijakan. Selain itu, timbul masalah lain dalam hal mendorong keadilan yang tidak adil, pejabat senior yang dinilai tidak akan dapat memberikan kesempatan yang seluas-luasnya untuk promosi sehingga menimbulkan keluhan dari karyawan. Namun, masalah gaji dan keamanan kerja cukup memuaskan.

Selain itu, fenomena motivasi karyawan pada Bank Aceh Syariah Cabang Bireuen dapat dilihat bahwa karyawan merasa kurang nyaman dengan pekerjaannya saat ini karena kurang mampu memberikan pelayanan yang prima kepada masyarakat, terutama pada saat pekerjaan tersebut repetitif dan membuat stres. Mereka harus berurusan dengan orang-orang yang tidak puas dengan pekerjaannya. Beban kerja yang diberikan atasan harus diselesaikan secepatnya sehingga masalah ini menyebabkan karyawan merasa tidak nyaman di tempat kerja. Selain itu kurangnya minat dari pejabat senior kepada karyawan yang berkinerja tinggi, seperti mengapresiasi prestasi kerja karyawan, membuat karyawan lain kurang semangat dan sembrono dalam bekerja, tentunya rendahnya motivasi kerja karyawan hingga saat ini dipengaruhi oleh faktor-faktor tertentu.

Fenomena budaya organisasi pada Bank Aceh Syariah Cabang Bireuen bertentangan dengan budaya organisasi yang diatur dengan prinsip ISLAMI, pengakuan pekerja yang menunjukkan adanya konflik internal antara pihak atasan dan bawahan, terutama dalam hal perbedaan dalam pengambilan kebijakan, kurang harmonis hubungan antara atasan dan bawahan, tidak amanah antar rekan kerja, ada perbedaan 
kepentingan, apabila terjadi kesalahpahaman tentang persepsi pengambilan keputusan atau kebijakan dalam negosiasi, hal ini berdampak negatif terhadap peningkatan kinerja karyawan, namun demikian setiap prosedur kerja masih berlangsung secara terintegrasi dan teratur pada Bank Aceh Syariah Cabang Bireuen.

Seperti yang dikemukakan oleh Turner (1994) yang menyatakan bahwa budaya dalam organisasi pada dasarnya mengarah pada perilaku yang sesuai, melibatkan dan memotivasi setiap individu yang ada di dalamnya, serta berusaha mencari solusi dalam situasi yang tidak pasti, mereka menyatakan bahwa terdapat hubungan antara budaya organisasi dan kinerja karyawan. Pemahaman ini memberikan dasar pemikiran bahwa setiap individu yang terlibat akan bekerja sama untuk menciptakan kondisi kerja yang ideal untuk menciptakan suasana yang mendukung upaya yang diharapkan.

Penelitian sebelumnya yang meneliti budaya organisasi dan pengaruhnya terhadap kinerja karyawan dilakukan oleh Edyatmo (2013). Hasil penelitian menunjukkan bahwa budaya organisasi berpengaruh positif dan signifikan terhadap kinerja pegawai, artinya jika budaya organisasi berkembang maka kinerja pegawai akan meningkat. Bertentangan dengan pengalaman yang terjadi dengan Bank Aceh Syariah Cabang Bireuen, budaya organisasi pada Bank Aceh Syariah Cabang Bireuen tidak berjalan dengan baik. Padahal konsep budaya organisasi di perusahaan ini ISLAMI. Topik ini dipandang perlu untuk penelitian yang menentukan motivasi dan kepuasan kerja sebagai variabel mediasi pada Bank Syariah Aceh Cabang Bireuen. Oleh karena itu, peneliti tertarik untuk menganalisis penelitian ini dengan judul peran motivasi kerja dan kepuasan kerja dalam memediasi pengaruh budaya organisasi terhadap kinerja karyawan pada PT. Bank Aceh Syariah Cabang Bireuen.

\section{TINJAUAN PUSTAKA Kinerja}

Kinerja karyawan sangat diperlukan karena dengan kinerja tersebut akan diketahui cakupan kemampuan karyawan dalam melaksanakan tugas yang diberikan kepadanya. Oleh karena itu, perlu ditetapkan kriteria yang jelas dan terukur yang secara bersamasama ditetapkan sebagai acuan. Mahmood et al. (2018) menjelaskan bahwa kinerja karyawan merupakan elemen penting dalam organisasi yang efektif. Tujuan utamanya adalah untuk mencapai kinerja karyawan yang sangat baik yang akan menghasilkan keberhasilan yang efektif dan berdampak signifikan terhadap efisiensi organisasi. Kinerja adalah proses yang direferensikan dan diukur selama periode waktu tertentu berdasarkan kondisi atau perjanjian yang telah ditentukan sebelumnya (Edison, 2016). Selain itu, Moeheriono (2012) menjelaskan bahwa kinerja merupakan cerminan dari tingkat keberhasilan implementasi suatu program atau kebijakan kegiatan untuk mencapai tujuan, sasaran dan visi dan misi yang ditetapkan dalam perencanaan strategis organisasi. Sementara itu, Sinambela et al. (2012) mengemukakan bahwa kinerja karyawan diartikan sebagai kemampuan karyawan untuk melakukan keterampilan tertentu. Menurut Akdon (2011), kinerja adalah sejauh mana seseorang bermain dengannya dalam mengimplementasikan strategi organisasi, baik dalam mencapai tujuan tertentu yang terkait dengan peran individu, maupun dengan menunjukkan kompetensi yang ditentukan terkait dengan organisasi. Ini adalah konsep multi-dimensi yang mencakup tiga aspek: kinerja, bakat, dan sikap berprestasi.

\section{Motivasi Kerja.}

Motivasi merupakan kekuatan pendorong bagi karyawan untuk bekerja sesuai dengan harapan perusahaan. Pemberian motivasi kepada karyawan dapat mempengaruhi operasional perusahaan dalam meningkatkan efisiensi kerja. Peningkatan motivasi pada karyawan berubah menjadi proses pencapaian tujuan manajemen sumber daya manusia. Motivasi berasal dari bahasa latin movere yang artinya mendorong atau bergerak. Motivasi merupakan desakan atau kekacauan untuk memenuhi berbagai kebutuhan manusia sesuai dengan kebutuhannya sendiri (Afin, 2012). Sedangkan menurut Kadarisma (2012) motivasi kerja adalah dorongan seseorang untuk berperilaku dan bekerja secara aktif dan baik sesuai dengan tugas dan kewajiban yang diberikan kepadanya.

\section{Kepuasan Kerja}

Kepuasan kerja adalah bagaimana perasaan seseorang terhadap pekerjaannya yang dihasilkan dari sikapnya terhadap berbagai aspek (Suwatno \& Priansa, 2011). Pandangan lain menyatakan bahwa kepuasan kerja merupakan ekspresi dari perasaan individu tentang pekerjaan dan berdampak pada operasional organisasi (Chatzoglou et al., 2011). Namun secara umum, istilah kepuasan kerja sering digunakan untuk mendapatkan gambaran yang lebih jelas tentang definisi kepuasan kerja, berikut definisi kepuasan kerja menurut beberapa ahli: 
Menurut Ardana (2012) menyatakan bahwa kepuasan kerja yang rendah dapat menimbulkan berbagai dampak negatif seperti penurunan disiplin kerja, penurunan semangat kerja, serta seringnya terjadi kesalahan dalam pekerjaan sehingga mengakibatkan penurunan produktivitas kerja. Sedangkan Bakotić dan Fiskovića (2013) menjelaskan bahwa kepuasan kerja pada umumnya ditunjukkan oleh karyawan dengan menyukai pekerjaan itu sendiri dan tingkat kenikmatan dalam menjalankan usaha. Secara umum dapat dikatakan bahwa kepuasan kerja merupakan rasa nyaman dan hubungan yang positif antar karyawan (Hasibuan, 2012).

\section{Budaya Kerja}

Norma yang disepakati adalah budaya, aturan yang disepakati dan dilanggar akan dikenakan sanksi. Grup perusahaan yang berorientasi bisnis dan menguntungkan akan membentuk kebiasaan yang mengarah pada pendapatan dengan cara kerja atau sistem kerja yang benar. Menurut Kreitner dan Kinicki (2014), budaya organisasi adalah nilai dan kepercayaan bersama yang mendasari identitas perusahaan. Selain itu, budaya organisasi Robbins \& Coulter (2012) adalah nilai-nilai, prinsip, tradisi dan sikap yang mempengaruhi perilaku anggota organisasi. Selain itu, Rivai dan Mulyadi (2012) menyatakan bahwa budaya organisasi merupakan kerangka kerja yang memandu karyawan dalam perilaku sehari-hari dan proses pengambilan keputusan serta memandu tindakannya untuk mencapai tujuan organisasi. Sementara itu, Robbins dan Coulter (2012) menyatakan bahwa budaya organisasi adalah nilai, prinsip, tradisi dan cara kerja yang dimiliki bersama oleh anggota organisasi dan mempengaruhi pola perilaku mereka. Selain itu, Riani (2011) mengemukakan bahwa budaya organisasi merupakan nilai-nilai dasar, keyakinan dan prinsip yang menjadi dasar sistem manajemen, serta praktik dan perilaku yang mengembangkan dan memperkuat prinsip tersebut

\section{METODOLOGI PENELITIAN}

Penelitian ini dilakukan untuk melihat pengaruh budaya organisasi terhadap kinerja karyawan melalui motivasi dan kepuasan kerja karyawan. Bank Aceh Syariah Cabang Bireuen memiliki 114 responden dalam penghitungan populasi, data kuesioner yang dikirim ke responden melalui email untuk mengumpulkan data penelitian. Untuk setiap peserta, ada 114 salinan kuestioner yang dikembalikan oleh responden pada saat itu, penelitian ini menggunakan metode kuantitatif karena sangatlah membantu untuk memeriksa hubungan dan memahami bagaimana hal ini dapat memengaruhi satu sama lain.

Kuesioner ini dibuat setelah mereview beberapa hasil penelitian sebelumnya, variabel dependen, kinerja karyawan diukur dengan 4 indikator menurut Tsui dalam Mas'ud, (2004) yaitu kualitas pekerjaan, jumlah pekerjaan, kreativitas dan kemampuan. Sedangkan variabel mediasi ada 2 (dua) macam, yang pertama adalah variabel motivasi yang diukur dengan 5 indikator menurut Rivai (2005), yaitu rasa aman dalam bekerja, mendapatkan gaji yang adil dan kompetitif, lingkungan kerja yang menyenangkan, penghargaan atas prestasi kerja, dan perlakuan adil dari manajemen. Mediator kedua adalah kepuasan kerja yang diukur dengan 5 indikator menurut Ward dan Sloane (1999) dalam Koesmono (2005) yaitu hubungan dengan rekan kerja, hubungan dengan pimpinan, kesempatan promosi, gaji, dan keamanan kerja. Sedangkan variabel bebas adalah budaya organisasi yang diukur dengan 5 indikator menurut Boke dan Nalla (2009); yaitu peraturan, jarak dengan atasan, kepercayaan, profesionalisme, dan integrasi. Setiap data harus menunjukkan bahwa semua variabel memiliki nilai Construct Reliability (CR) lebih besar dari 0,70 dan nilai Variance Extracted (VE) lebih besar dari 0,5, juga semua konstruk memiliki validitas diskriminasi yang baik, masing-masing dari akar kuadrat VE terlihat. Struktur laten harus memiliki nilai yang lebih tinggi dari nilai korelasinya. Keandalan konstruksi sangat penting untuk memproses analisis lebih lanjut dalam penelitian ini. Setiap Jawaban instrumen yang menggunakan skala likert memiliki gradien dari sangat positif ke lebih negatif, termasuk rentang 1 sangat tidak setuju dan 5 sangat setuju

\section{HASIL PENELITIAN}

Semua kuesioner yang dibagikan kepada semua responden dikirim kembali dengan 114 kuesioner. Data yang terkumpul terlebih dahulu diuji menggunakan SPSS versi 16 dan kemudian teknik analisis Structural Equation Model (SEM). Pengujian langkah analisis SEM, yang terdiri dari pengujian validitas struktur eksogen dan struktur endogen, pengujian validitas instrumen menggunakan Confirmation Factor Analysis (CFA) untuk setiap konstruk, yaitu nilai item ekspresi adalah melihat nilai Factor Load masing-masing indikator dan hasil yang diperoleh untuk masing-masing memiliki nilai $\geq 0,6$.. Selain itu, uji reliabilitas struktur berbasis data menunjukkan bahwa semua variabel memiliki nilai Cunstruct Reliability (CR) lebih besar dari 0,70 dan nilai Variance Extracted (VE) lebih besar dari 0,5, serta semua struktur yang tersembunyi memiliki nilai validitas yang berbeda. Hasil penelitian menunjukkan bahwa akar kuadrat VE setiap struktur laten memiliki nilai yang lebih tinggi dari nilai korelasinya.

Setelah melalui tahap analisis SEM dilakukan Uji Asumsi SEM, maka analisis SEM memerlukan serangkaian pengujian yang bertujuan untuk melihat apakah semua alat memenuhi kriteria yang dipersyaratkan. Ada 4 perangkat studi yang akan diuji, 
yaitu pengujian pengukuran sampel, pengujian normalitas data, outlier data, multikolinearitas dan singularitas., kemudian dilakukan uji SEM model penuh pada semua variabel eksogen dan endogen yang digabungkan dan utuh melalui matrik varian dan kovarian dan model penuh disebut juga model eksplorasi. Untuk mengetahui hasil pengolahan data menggunakan Amos dapat dilihat pada Gambar 2.

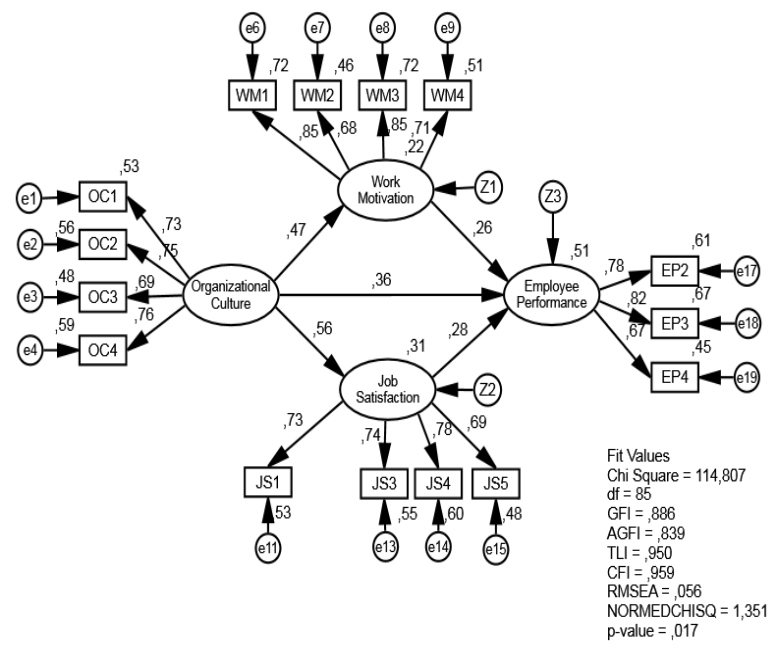

\section{Gambar 2 CFA Konstruk Full Model sebelum Dimodifikasi}

Selanjutnya uji kesesuaian model dapat dilihat pada Tabel 1 berikut:

\begin{tabular}{llcc}
\hline $\begin{array}{c}\text { Goodness of } \\
\text { Fit Index }\end{array}$ & \multicolumn{1}{c}{$\begin{array}{c}\text { Cut-off } \\
\text { Value }\end{array}$} & $\begin{array}{c}\text { Hasil } \\
\text { Analisis }\end{array}$ & $\begin{array}{c}\text { Evaluasi } \\
\text { Model }\end{array}$ \\
\hline $\mathrm{X}^{2}$-Chi- & Diharapkan & 114,807 & Baik \\
Square & Kecil & & \\
Probability & $\geq 0.05$ & 0.017 & Marginal \\
GFI & $\geq 0.90$ & 0.886 & Marginal \\
AGFI & $\geq 0.90$ & 0.839 & Marginal \\
CFI & $\geq 0.95$ & 0.959 & Baik \\
TLI & $\geq 0.95$ & 0.950 & Baik \\
CMIN/DF & $\leq 2$ & 1,35 & Baik \\
RMSEA & $\leq 0.08$ & 0.056 & Baik \\
\hline
\end{tabular}

Berdasarkan table 1 di atas memperlihatkan hasil akhir analisis confirmatory factor analysis full model. Secara umum semua kontruk yang digunakan dalam membentuk model penelitian ini, baik pada analisis konfirmatori (CFA), nilai regresi antar kontruk maupun uji goodness of fit yang terdiri dari $\mathrm{X}^{2}$-ChiSquare, CFI, dan TLI, CMIN/DF dan RMSEA sudah memenuhi kriteria yang disyaratkan kecuali Probability, GFI, dan AGFI yang berada pada nilai belum baik, oleh karena itu perlu dilakukan modifikasi.

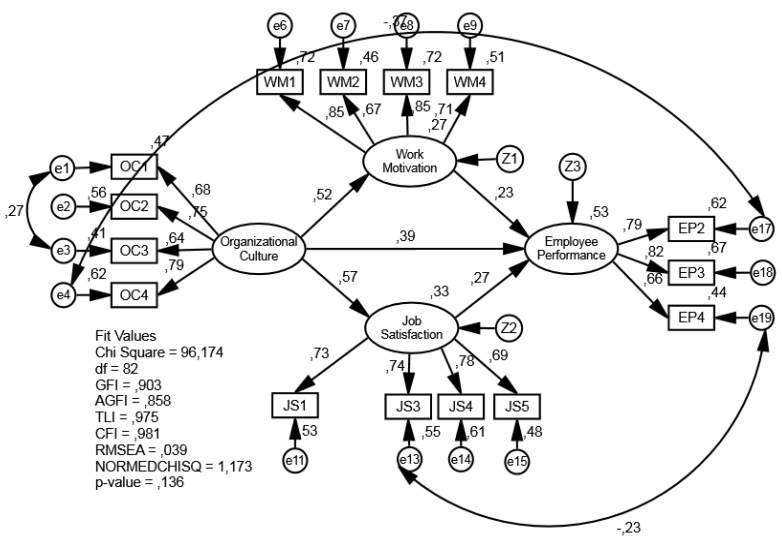

\section{Gambar 3 CFA Konstruk Full Model setelah Dimodifikasi}

Selanjutnya uji kesesuaian model dapat dilihat pada Tabel 2 berikut:

\begin{tabular}{llcc}
\hline $\begin{array}{c}\text { Goodness of } \\
\text { Fit Index }\end{array}$ & \multicolumn{1}{c}{$\begin{array}{c}\text { Cut-off } \\
\text { Value }\end{array}$} & $\begin{array}{c}\text { Hasil } \\
\text { Analisis }\end{array}$ & $\begin{array}{c}\text { Evaluasi } \\
\text { Model }\end{array}$ \\
\hline X $^{2}$-Chi- & Diharapkan & 96,178 & Baik \\
Square & Kecil & & \\
Probability & $\geq 0.05$ & 0.136 & Baik \\
GFI & $\geq 0.90$ & 0.903 & Baik \\
AGFI & $\geq 0.90$ & 0.858 & Marginal \\
CFI & $\geq 0.95$ & 0.981 & Baik \\
TLI & $\geq 0.95$ & 0.975 & Baik \\
CMIN/DF & $\leq 2$ & 1,17 & Baik \\
RMSEA & $\leq 0.08$ & 0.039 & Baik \\
\hline
\end{tabular}

Berdasarkan gambar 3 dan tabel 2 di atas memperlihatkan hasil akhir analisis confirmatory factor analysis full model. Secara umum semua kontruk yang digunakan dalam membentuk model penelitian ini, baik pada analisis konfirmatori (CFA), nilai regresi antar kontruk maupun uji goodness of fit yang terdiri dari $\mathrm{X}^{2}$ Chi-Square, probability, GFI, CFI, TLI, CDMIN/DF dan RMSEA, telah memenuhi kriteria yang disyaratkan kecuali AGFI yang berada pada nilai hampir baik, maka model dapat disimpulkan telah fit dan mendukung data, sehingga model sudah dapat diterima sehingga model layak digunakan dalam penelitian ini (Byrne, 2016).

Untuk melihat seberapa besar pengaruh langsung, tidak langsung dan pengaruh total ditampilkan dalam Tabel 3:

Tabel 3

Pengujian Pengaruh Langsung, Tidak Langsung dan Pengaruh Total

\begin{tabular}{ccccc}
\hline & $\begin{array}{c}\text { Buda } \\
\text { ya } \\
\text { Organis } \\
\text { asi }\end{array}$ & $\begin{array}{c}\text { Kep } \\
\text { uasan } \\
\text { Kerja }\end{array}$ & $\begin{array}{c}\text { Mot } \\
\text { ivasi } \\
\text { Kerja }\end{array}$ & $\begin{array}{c}\text { Kine } \\
\text { rja } \\
\text { Karyaw } \\
\text { an }\end{array}$ \\
\hline Direct Effect & & & & \\
\hline $\begin{array}{c}\text { Kepuasan } \\
\text { Kerja } \\
\text { Motivasi }\end{array}$ & 0,560 & 0,000 & $\begin{array}{l}0,00 \\
0\end{array}$ & 0,000 \\
& 0,470 & 0,000 & 0,00 & 0,000
\end{tabular}




\begin{tabular}{|c|c|c|c|c|}
\hline & \multicolumn{3}{|c|}{0} \\
\hline $\begin{array}{r}\text { Kinerja } \\
\text { Karyawan }\end{array}$ & 0,356 & 0,276 & $\begin{array}{l}0,26 \\
2\end{array}$ & 0,000 \\
\hline \multicolumn{5}{|c|}{ Indirect Effects } \\
\hline $\begin{array}{l}\text { Kepuasan } \\
\text { _Kerja }\end{array}$ & 0,000 & 0,000 & $\begin{array}{l}0,00 \\
0\end{array}$ & 0,000 \\
\hline $\begin{array}{l}\text { Motivasi } \\
\text { Kerja }\end{array}$ & 0,000 & 0,000 & $\begin{array}{l}0,00 \\
0\end{array}$ & 0,000 \\
\hline $\begin{array}{r}\text { Kinerja } \\
\text { Karyawan }\end{array}$ & 0,278 & 0,000 & $\begin{array}{l}0,00 \\
0\end{array}$ & 0,000 \\
\hline \multicolumn{5}{|l|}{ Total Effects } \\
\hline $\begin{array}{l}\text { Kepuasan } \\
\text { Kerja }\end{array}$ & 0,560 & 0,000 & $\begin{array}{l}0,00 \\
0\end{array}$ & 0,000 \\
\hline $\begin{array}{l}\text { Motivasi } \\
\text { Kerja }\end{array}$ & 0,470 & 0,000 & $\begin{array}{l}0,00 \\
0\end{array}$ & 0,000 \\
\hline $\begin{array}{r}\text { Kinerja } \\
\text { Karyawan }\end{array}$ & 0,634 & 0,276 & $\begin{array}{l}0,26 \\
2\end{array}$ & 0,000 \\
\hline
\end{tabular}

Hasil pengujian efek memediasi (intervening) hubungan variabel budaya organisasi dengan variabel kinerja karyawan yang dimediasi oleh variabel motivasi kerja ditampilkan dalam bentuk Gambar 4:

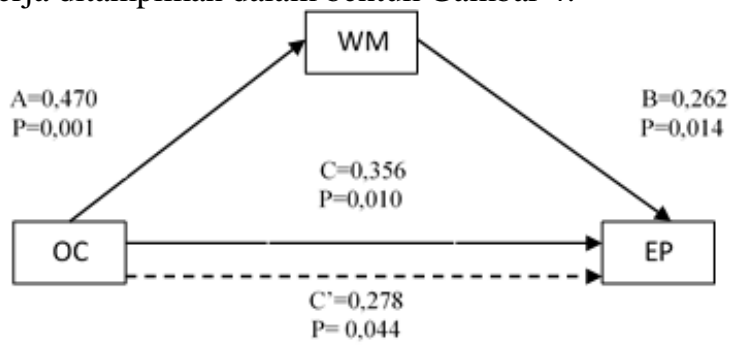

Gambar 4. Hasil Uji Efek Mediasi

signifikansi jalur $\mathrm{C}^{\prime}$ adalah signifikan. Hasil penelitian ini menyebutkan bahwa variabel $\mathrm{M}$

Tabel 4

Hasil Uji Hipotesis

\begin{tabular}{|c|c|c|c|c|c|c|}
\hline No & Pernyataan Hipotesis & $\begin{array}{l}\text { Standard } \\
\text { Estimate }\end{array}$ & S.E. & C.R. & $\mathrm{P}$ & Kesimpulan \\
\hline \multirow[t]{5}{*}{1} & Terdapat pengaruh signifikan & \multirow{5}{*}{0,470} & \multirow{5}{*}{0,152} & \multirow{5}{*}{4,195} & \multirow{5}{*}{0,001} & \\
\hline & Budaya Organisasi terhadap & & & & & Data \\
\hline & Motivasi Kerja Pegawai pada & & & & & Mendukung \\
\hline & PT. Bank Aceh Syariah & & & & & Model \\
\hline & Cabang Bireuen. & & & & & \\
\hline \multirow[t]{4}{*}{2} & Terdapat pengaruh signifikan & \multirow{4}{*}{0,560} & \multirow{4}{*}{0,144} & \multirow{4}{*}{4,580} & \multirow{4}{*}{0,001} & \\
\hline & Budaya Organisasi terhadap & & & & & Data \\
\hline & Kepuasan Kerja Pegawai pada & & & & & Mendukung \\
\hline & $\begin{array}{l}\text { PT. Bank Aceh Syariah } \\
\text { Cabang Bireuen. }\end{array}$ & & & & & Model \\
\hline \multirow[t]{3}{*}{3} & Terdapat pengaruh signifikan & \multirow[b]{3}{*}{0,356} & \multirow[b]{3}{*}{0,173} & \multirow[b]{3}{*}{2,572} & \multirow[b]{3}{*}{0,010} & \\
\hline & Budaya Organisasi terhadap & & & & & Data \\
\hline & $\begin{array}{l}\text { Kinerja Pegawai pada PT. } \\
\text { Bank Aceh Syariah Cabang } \\
\text { Bireuen. }\end{array}$ & & & & & $\begin{array}{l}\text { Mendukung } \\
\text { Model }\end{array}$ \\
\hline 4 & Terdapat pengaruh signifikan & 0,262 & 0,099 & 2,445 & 0,014 & Data \\
\hline
\end{tabular}


Motivasi Kerja terhadap

Kinerja Pegawai pada PT.

Bank Aceh Syariah Cabang

Bireuen.

5 Terdapat pengaruh signifikan

Kepuasan Kerja terhadap

Kinerja Pegawai pada PT.

Bank Aceh Syariah Cabang

Bireuen.

6 Terdapat pengaruh signifikan

Budaya Organisasi terhadap

kinerja pegawai melalui

Motivasi Kerja Pegawai pada

PT. Bank Aceh Syariah

Cabang Bireuen.

7 Terdapat pengaruh signifikan

Budaya Organisasi terhadap

kinerja pegawai melalui

Kepuasan Kerja pada Pegawai pada PT. Bank Aceh Syariah Cabang Bireuen.

\section{DISKUSI}

Bagian ini membahas hasil penelitian yang diperoleh melalui analisis model SEM. Selain itu, pada bagian ini akan ditekankan tanggapan terhadap hipotesis dan teori yang relevan, serta pengujian hipotesis yang dibuat untuk memperoleh bukti empiris dari penelitian sebelumnya. Berdasarkan hasil analisis dapat dijelaskan sebagai berikut:

1. Pengaruh Budaya Organisasi terhadap Motivasi Kerja

Berdasarkan hasil pengujian yang dilakukan dengan menggunakan SEM melalui program Amos terbukti bahwa budaya organisasi berpengaruh terhadap motivasi kerja. Hasil analisis membuktikan bahwa nilai probabilitas yang dihasilkan dari model sebesar 0,001 $(<0,05)$, sehingga dapat dikatakan bahwa budaya organisasi berpengaruh signifikan terhadap motivasi kerja. Artinya semakin baik budaya organisasi maka semakin baik pula motivasi kerja karyawan pada PT. Bank Syariah Aceh cabang Bireuen. Artinya budaya organisasi berpengaruh langsung terhadap motivasi kerja karyawan sangat kuat, sehingga peningkatan motivasi kerja karyawan di Bank Aceh Syariah Cabang Bireuen melalui budaya organisasi lebih efektif. Hasil penelitian ini sejalan dengan Greeks dan Mulyanto (2014), hasil penelitian menunjukkan bahwa budaya organisasi berpengaruh positif dan signifikan terhadap motivasi kerja karyawan. Selain itu, Hardiyana et al. (2013) hasil menunjukkan bahwa budaya organisasi berpengaruh positif dan signifikan terhadap motivasi kerja.

Berdasarkan informasi diatas maka dapat disimpulkan bahwa penelitian ini mengambil hipotesis pertama yang menyatakan bahwa budaya organisasi
Mendukung

Model

Data

$0,130 \quad 2,256 \quad 0,024 \quad \begin{gathered}\text { Mendukung } \\ \text { Model }\end{gathered}$

Data

Mendukung

Model

(parsial

mediation)

Data

Mendukung

Model (full

mediation)

berpengaruh signifikan terhadap motivasi kerja karyawan pada Bank Aceh Syariah Cabang Bireuen.

2. Pengaruh Budaya Organisasi terhadap Kepuasan Kerja

Berdasarkan hasil pengujian menggunakan SEM melalui program Amos terbukti bahwa budaya organisasi berpengaruh terhadap kepuasan kerja. Hasil analisis membuktikan bahwa nilai probabilitas yang diperoleh dari model sebesar 0,001 $(<0,05)$, sehingga dapat dikatakan budaya organisasi berpengaruh signifikan terhadap kepuasan kerja. Artinya semakin baik budaya organisasi maka semakin baik pula kepuasan kerja karyawan pada PT. Bank Syariah Aceh Cabang Bireuen. Artinya budaya organisasi berpengaruh langsung terhadap motivasi kerja sangat kuat, sehingga peningkatan kepuasan kerja karyawan melalui budaya organisasi lebih efektif di Bank Aceh Syariah Cabang Bireuen. Hasil penelitian ini juga sejalan dengan penelitian Munizu (2010) yang meneliti pengaruh budaya organisasi terhadap kepuasan kerja. Menurut hasil penelitiannya menunjukkan bahwa budaya organisasi berpengaruh terhadap kepuasan kerja.

Berdasarkan informasi diatas maka dapat disimpulkan bahwa penelitian ini mengambil hipotesis kedua yang menyatakan bahwa budaya organisasi berpengaruh signifikan terhadap kepuasan karyawan di PT. Bank Aceh Syariah Cabang Bireuen.

\section{Pengaruh Budaya terhadap Kinerja Karyawan}

Berdasarkan hasil pengujian menggunakan program SEM melalui Amos terbukti bahwa budaya organisasi berpengaruh terhadap kinerja karyawan. Hasil analisis membuktikan bahwa nilai probabilitas yang diperoleh dari model adalah $0,010 \quad(<0,05)$, 
sehingga dinyatakan berpengaruh signifikan terhadap kinerja karyawan. Artinya semakin baik aliran budaya organisasi maka semakin baik pula kinerja karyawan di PT. Bank Aceh Syariah Cabang Bireuen. Hasil penelitian ini juga sejalan dengan penelitian Sunaryo (2013) yang meneliti pengaruh budaya organisasi terhadap peningkatan kinerja karyawan. Hasil penelitian menyatakan bahwa budaya organisasi berpengaruh terhadap kinerja karyawan.

Berdasarkan informasi di atas, dapat disimpulkan bahwa penelitian ini mengambil hipotesis yang menyatakan bahwa budaya berpengaruh signifikan terhadap kinerja karyawan pada PT. Bank Aceh Syariah Cabang Bireuen.

4. Pengaruh Motivasi Kerja terhadap Kinerja Pegawai Berdasarkan hasil pengujian yang dilakukan dengan menggunakan program SEM melalui Amos terbukti bahwa motivasi kerja berpengaruh terhadap kinerja karyawan. Hasil analisis membuktikan bahwa nilai probabilitas yang diperoleh dari model adalah $0,014(<0,05)$, sehingga dinyatakan terdapat pengaruh signifikan kepuasan kerja terhadap kinerja karyawan. Artinya semakin baik motivasi kerja maka semakin baik pula kinerja karyawan pada PT. Bank Aceh Syariah Cabang Bireuen. Hasil penelitian ini juga disampaikan oleh Kharis et al. (2015) salah satu hasil penelitiannya yang menyatakan bahwa motivasi berpengaruh positif terhadap kinerja karyawan. Penelitian lain oleh Febriani dari Kasmirudin (2016) hasil penelitian mereka juga menyebutkan bahwa ada hubungan yang signifikan antara motivasi dengan kinerja karyawan.

Berdasarkan informasi di atas, dapat disimpulkan bahwa penelitian ini menerima hipotesis bahwa motivasi kerja berpengaruh signifikan terhadap kinerja karyawan pada Bank Aceh Syariah Cabang Bireuen.

5. Pengaruh Kepuasan Kerja terhadap Kinerja Karyawan

Berdasarkan hasil pengujian yang dilakukan dengan menggunakan SEM melalui program Amos terbukti bahwa kepuasan kerja berpengaruh terhadap kinerja karyawan. Hasil analisis membuktikan bahwa nilai probabilitas yang diperoleh dari model adalah $0,024(<0,05)$, sehingga dapat dikatakan kepuasan kerja berpengaruh signifikan terhadap kinerja pegawai. Artinya semakin baik kepuasan kerja karyawan maka semakin baik pula kinerja karyawan. Hasil penelitian ini sejalan dengan penelitian Tobing (2009) dimana hasil penelitiannya menyatakan bahwa kepuasan kerja berpengaruh positif signifikan terhadap kinerja karyawan. Penelitian lain oleh Putri dan Latrini (2013) menyatakan bahwa kepuasan kerja berpengaruh positif terhadap kinerja karyawan.

Berdasarkan informasi di atas, dapat disimpulkan bahwa penelitian ini mengambil hipotesis kelima yang menyatakan bahwa kepuasan kerja berpengaruh signifikan terhadap kinerja karyawan pada Bank Aceh Syariah Cabang Bireuen.

\section{Motivasi Kerja Memediasi Budaya Organisasi dengan Kinerja Karyawan pada PT. Bank Aceh Syariah Cabang Bireuen}

Hasil penelitian ini menunjukkan bahwa kinerja karyawan dipengaruhi tidak hanya oleh budaya organisasi, tetapi juga oleh variabel motivasi kerja. Meskipun motivasi kerja merupakan variabel mediator yang secara tidak langsung mempengaruhi variabel budaya organisasi dan kinerja karyawan, hal ini dapat dilihat dari hasil pengujian dengan mengacu pada teori Baron dan Kenny (1986) dengan alat uji sobel yang dikembangkan oleh Preacher dan Hayes (2004). Baron dan Kenny (1986) menjelaskan prosedur untuk analisis sederhana variabel mediasi melalui regresi. Pada dasarnya menurut Baron dan Kenny (1986), mensyaratkan bahwa sebuah variabel dapat dikatakan menjadi mediator jika hasilnya adalah: (1) Jalur-c : signifikan (2) Jalur-a : signifikan (3) Jalur-b : signifikan (4) Jalur-c' : tidak signifikan. Untuk dinyatakan sebagai mediator, hubungan $\mathrm{X}$ ke $\mathrm{Y}$ pada persamaan ke 3 haruslah tidak signifikan (nol), atau disebut dengan full mediation. Tapi jika persamaan 1 sampai dengan persamaan 3 terpenuhi, namun persamaan 4 tidak, maka disebut dengan partial mediation, sehingga hipotesis keenam (H6) diterima.

Menurut teori Baron \& Kenny, (1986) kriteria nilai probabilitas yang seharusnya pada jalur C' adalah tidak signifikan, dan jika nilai kriteria ini terlampaui, maka terjadi mediasi sempurna (full mediation), sedangkan jika nilai probabilitas pada jalur $\mathrm{C}^{\prime}$ signifikan $<0,05$, maka terjadi parsial mediasi atau variabel intervening memberikan dampak pengaruh secara parsial antara variabel eksogen terhadap variabel endogen. Perhitungan dengan menggunakan sobel test an interactive calculation tool for mediation tests yang telah dilakukan diperoleh hasil bahwa nilai probabilitas pada jalur $C^{\prime}$ signifikan $(0,044)$ artinya bahwa variabel motivasi kerja memediasi secara mediasi parsial (partial mediation) antara variabel budaya organisasi dengan kinerja karyawan pada PT. Bank Aceh Syariah Cabang Bireuen.

\section{Kepuasan Kerja Memediasi Budaya Organisasi dengan Kinerja Karyawan pada PT. Bank Aceh Syariah Cabang Bireuen}

Kinerja karyawan tidak hanya dipengaruhi secara langsung oleh budaya organiasi, tetapi juga 
kepuasan kerja. Apakah kepuasan kerja berperan sebagai variabel perantara yang secara tidak langsung mempengaruhi antara budaya organisasi dan kinerja karyawan dapat dilihat dari hasil pengujian dengan mengacu pada teori Baron \& Kenny, (1986) dengan alat uji sobel yang dikembangkan oleh Preacher \& Hayes, (2004). Baron \& Kenny, (1986) menjelaskan prosedur analisis variabel mediator secara sederhana melalui regresi. Intinya menurut Baron \& Kenny, (1986) mensyaratkan bahwa sebuah variabel dapat dikatakan menjadi mediator jika hasilnya adalah: (1) Jalur-c : signifikan (2) Jalur-a : signifikan (3) Jalur-b : signifikan (4) Jalur-c' : tidak signifikan. Untuk dinyatakan sebagai mediator, hubungan $\mathrm{X}$ ke $\mathrm{Y}$ pada persamaan ke 3 haruslah tidak signifikan (nol), atau disebut dengan full mediation. Tapi jika persamaan 1 sampai dengan persamaan 3 terpenuhi, namun persamaan 4 tidak, maka disebut dengan partial mediation, sehingga hipotesis ketujuh (H7) diterima.

Menurut teori Baron \& Kenny, (1986) kriteria nilai probabilitas yang seharusnya pada jalur C' adalah tidak signifikan, dan jika nilai kriteria ini terlampaui, maka terjadi mediasi sempurna (full mediation), sedangkan jika nilai probabilitas pada jalur C' signifikan $<0,05$, maka terjadi parsial mediasi atau variabel intervening memberikan dampak pengaruh secara parsial antara variabel eksogen terhadap variabel endogen. Perhitungan dengan menggunakan sobel test an interactive calculation tool for mediation tests yang telah dilakukan diperoleh hasil bahwa nilai probabilitas pada jalur $C^{\prime}$ tidak signifikan $(0,062)$ artinya bahwa variabel kepuasan kerja memediasi secara mediasi sempurna (fully mediation) antara variabel budaya organisasi dengan kinerja karyawan pada PT. Bank Aceh Syariah Cabang Bireuen.

\section{KESIMPULAN}

Berdasarkan tujuan penelitian yang telah diuraikan sebelumnya, maka dapat dikemukakan beberapa kesimpulan penelitian sebagai berikut:

1. Hasil penelitian ini menunjukkan bahwa variabel Budaya Organisasi berpengaruh positif dan signifikan terhadap Motivasi Kerja Pegawai pada PT. Bank Aceh Syariah Cabang Bireuen. Hasil ini telah memperkuat dan menambah jumlah literatur ilmiah dalam lingkup teori manajemen sehubungan dengan pengaruh variabel Budaya Organisasi terhadap Motivasi Kerja.

2. Hasil penelitian ini menunjukkan bahwa variabel Budaya Organisasi berpengaruh positif dan signifikan terhadap Kepuasan Kerja Pegawai pada PT. Bank Aceh Syariah Cabang Bireuen. Hasil ini telah memperkuat dan menambah jumlah literatur ilmiah dalam lingkup teori manajemen sehubungan dengan pengaruh variabel Budaya Organisasi terhadap Kepuasan Kerja.
3. Hasil penelitian ini menunjukkan bahwa variabel Budaya Organisasi berpengaruh positif dan signifikan terhadap Kinerja Pegawai pada PT. Bank Aceh Syariah Cabang Bireuen. Hasil ini telah memperkuat dan menambah jumlah literatur ilmiah dalam lingkup teori manajemen sehubungan dengan pengaruh variabel Budaya Organisasi terhadap Kinerja Pegawai.

4. Hasil penelitian ini menunjukkan bahwa variabel Motivasi Kerja berpengaruh positif dan signifikan terhadap kinerja Pegawai pada PT. Bank Aceh Syariah Cabang Bireuen. Hasil ini telah memperkuat dan menambah jumlah literatur ilmiah dalam lingkup teori manajemen sehubungan dengan pengaruh variabel Motivasi Kerja terhadap Kinerja Pegawai.

5. Hasil penelitian ini menunjukkan bahwa variabel Kepuasan Kerja berpengaruh positif dan signifikan terhadap kinerja Pegawai pada PT. Bank Aceh Syariah Cabang Bireuen. Hasil ini telah memperkuat dan menambah jumlah literatur ilmiah dalam lingkup teori manajemen sehubungan dengan pengaruh variabel Kepuasan Kerja terhadap Kinerja Pegawai.

Hasil penelitian ini menunjukkan bahwa variabel Motivasi Kerja memediasi secara positif dan signifikan pengaruh Budaya Organisasi terhadap kinerja Pegawai pada PT. Bank Aceh Syariah Cabang Bireuen. Mediasi ini disebut parsial mediasi (partially mediation).

Hasil ini telah membantah penelitian sebelumnya yang dilakukan Yunanto dan Mulyanto (2014) menyatakan bahwa pengaruh langsung budaya organisasi terhadap kinerja pegawai lebih kecil dari pengaruh tidak langsung budaya organisasi terhadap kinerja pegawai dengan mediasi motivasi kerja, sehingga untuk meningkatkan kinerja pegawai lebih efektif melalui jalur tidak langsung.

Hasil penelitian ini menunjukkan bahwa variabel Kepuasan Kerja memediasi secara positif dan tidak signifikan pengaruh Budaya Organisasi terhadap kinerja Pegawai pada PT. Bank Aceh Syariah Cabang Bireuen. Mediasi ini full mediasi (fully mediation). Hasil ini telah membantah penelitian sebelumnya yang dilakukan Putra (2014) dalam tesisnya menguji efek mediating budaya organisasi terhadap kinerja perawat pada Badan Layanan Umum Daerah Rumah Sakit Jiwa Aceh melalui kepuasan kerja. Hasil penelitiannya menunjukkan bahwa pengaruh budaya organisasi terhadap kepuasan kerja perawat adalah positif, dan pengaruh kepuasan kerja terhadap kinerja perawat berpengaruh signifikan serta pengaruh budaya organisasi terhadap kinerja perawat adalah signifikan, dengan demikian pengujian ini menunjukkan adanya partially mediated. 


\section{REFERENSI}

Afin, Murtie, (2012). Menciptakan SDM Berkuwalitas, PT. Gelora Aksara Pratama. Jakarta.

Akdon, (2011). Strategic Management For Educational Management (Manajemen Strategik untuk Manajemen Pendidikan), Bandung: Alfabeta.

Ardana, K., N. Mujiati, dan I.W. Mudiartha U. (2012). Manajemen Sumber Daya Manusia. Yogyakarta: Graha Ilmu

Bakotić, D., \& Fiskovića, C. (2013). Relationship between Working Conditions and Job Satisfaction : The Case of Croatian Shipbuilding Company. 4(2), 206-213.

Baron, R. M. \& D. A. Kenny, (1986), The Moderator-Mediator Variable Distinction in Social Psychological Research: Conceptual, Strategic And Statistical Considerations, Journal of Personality and Social Psychology, pp. 1173-1182.

Boke dan Nalla (2009). Police organizational culture and job satisfaction: a comparison of law enforcement officers' perception in two midwestern states in the U.S. Journal of Criminal Justice and Security, 11,55-73.

Byrne, B. M. (2016). Structural Equation Modeling With AMOS. In Structural Equation Modeling With AMOS (3rd ed.). Routledge. https://doi.org/10.4324/9781410600219

Chatzoglou et al., 2011)

Chatzoglou, Prodromos D., Eftichia Vraimaki, Eleni Komsiou, Elena Polychrou, dan Anastastios D. Diamantidis, (2011), Factors Affecting Accountants' Job Satisfaction and Turnover Intentions: A Structural Equation Model. 8thInternational Conference on Enterprise Systems, Accounting and Logistics (8th ICESAL)

Edison. (2016). Manajemen Sumber Daya Manusia, Bandung : Alfabeta

Edyatmo, Setyo,. (2013). Pengaruh Kompensasi, Stres Kerja, Komitmen Organisasi, dan Budaya Organisasi terhadap Kinerja Karyawan PT. Transindo Surya Sarana Semarang, Jurnal Fakultas Ekonomi Universitas Semarang.

Hanaysha, J., \& Tahir, P. R. (2016). Examining the Effects of Employee Empowerment, Teamwork, and Employee Training on Job Satisfaction. Procedia - Social and Behavioral Sciences, 219, 272-282. https://doi.org/10.1016/j.sbspro.2016.05.016

Hardiyana, Aan., Sentot Iskandar, dan Leli Nurlaila (2013). Pengaruh Budaya Organisasi Dan Kompensasi Terhadap Motivasi Kerja Serta Implikasinya Terhadap Kinerja Guru, Jurnal Ekonomi, Bisnis \& Entrepreneurship Vol. 7, No. 2, Oktober 2013, 64-73.

Hasibuan, M. (2012). Manajemen Sumber Daya Manusia. Edisi Revisi. Cetakan keenam belas. Jakarta: PT Bumi Aksara. Jakarta.

Kadarisman, M. (2012). Manajemen Pengembangan Sumber Daya Manusia, Edisi Pertama, Cetakan pertama, Rajawali Press, Jakarta,

Koesmono, Teman, H. (2005). Pengaruh Budaya Organisasi Terhadap Motivasi dan Kepuasan Kerja Serta Kinerja Karyawan Pada Sub Sektor Industri Pengolahan Kayu Skala Menengah Di Jawa Timur, Jurnal Jurusan Ekonomi Manajemen, Fakultas Ekonomi Universitas Kristen Petra.

Kreitner, Robert dan Angelo Kinicki. (2014). Organizational behavioral-Ed. 5. Boston: McGraw-Hill.

Kristianto, Dian., Suharnomo \& Ratnawati, Intan., (2012). Pengaruh Kepuasan Kerja Terhadap Kinerja Karyawan Dengan Komitmen Organisasional Sebagai Variabel Intervening. Studi pada RSUD Tugurejo Semarang, Jurnal Universitas Diponegoro.

Luthans Fred., (2006). Perilaku Organisasi, edisi 10.Yogyakarta: Penerbit Andi.

Mahmood, R., Hee, O. C., Yin, O. S., \& Hamli, M. S. H. (2018). The Mediating Effects of Employee Competency on the Relationship between Training Functions and Employee Performance. International Journal of Academic Research in Business and Social Sciences, 8(7), 664-676. https://doi.org/10.6007/ijarbss/v8-i7/4410

Mathis, R.L dan Jackson., , (2011), Human Resource Management, Salemba Empat, Jakarta

Moeheriono. (2012). Pengukuran Kinerja Berbasis Kompetensi. Jakarta: Raja Grafindo Persada.

Munizu, Musran. (2010), Persepsi Budaya Organisasi dan Komitmen Terhadap Kepuasan Kerja Karyawan Bank, Jurnal Manajemen Fakultas Ekonomi Universitas Hasanuddin.

Novferma, N. (2016). Analisis kesulitan dan self-efficacy siswa SMP dalam pemecahan masalah matematika berbentuk soal cerita. Jurnal Riset Pendidikan Matematika, 3(1), 76-87. 
Oshagbemi, T. (1999). Academics and their managers: a comparative study in job satisfaction. https://doi.org/http://dx.doi.org/10.1108/00483489910249027

Preacher, K. J., \& Hayes, A. F. (2004). SPSS and SAS procedures for estimating indirect effects in simple mediation models. Behavior Research Methods, Instruments, and Computers, 36(4), 717-731. https://doi.org/10.3758/BF03206553

Putri, Asteria, Putu Yudha., \& Latrini, Yenni, Made., (2013). Pengaruh Kepuasan Kerja Terhadap Kinerja Karyawan Sektor Publik, Dengan In-Role Performance Dan Innovative Performance Sebagai Variabel Mediasi, Jurnal Fakultas Ekonomi dan Bisnis Universitas Udayana (Unud), Bali.

Riani, Asri Laksmi. (2011). Budaya Organisasi. Cetakan Pertama, Edisi Pertama.Yogyakarta: Graha Ilmu.

Rivai, Veithzal dan Ella Sagala, (2013). Manajemen Sumber Daya Manusia Untuk Perusahaan, Rajawali Pers, Jakarta.

Robbins, P. Stephen, and Mary Coulter (1996). Management (5th ed.), New Jersey: Prentice Hall, Inc.

Robbins, P. Stephen, and Mary Coulter (2014). Management. Twelfh Edition. UNited States: Pearson Education Limited

Robbins, Stephen .P., , (2002). Prinsip-prinsip Perilaku Organisasi, PT. Erlangga, Jakarta

Robbins, Stephen P, (2006), Perilaku Organisasi , Jakarta: PT. Indeks Gramedia.

Robbins, Stephen, , (2007), Perilaku Organisasi. Terj: Benyamin Molan. New Jersey: Prentice Hall, Inc.

Robbins, Stephen, P., , (1996), Organizational Behavior Concept, Controversiest, Applications, Engelwoods Cliffs: Prentice Hall. Inc.

Robbins,Stephen P. and Mary Coulter (2012). Management. New Jersey: Pearson Education, Inc.

Rowlingson, K. (2011). Does income inequality cause health and social problems? Joseph Rowntree Foundation, September, 51. http://www.jrf.org.uk/sites/files/jrf/inequality-income-socialproblems-full.pdf

Sari, R. N. I., \& Hadijah, H. S. (2016). Peningkatan Kinerja Karyawan Melalui Kepuasan Kerja Dan Disiplin Kerja. Jurnal Pendidikan Manajemen Perkantoran, 1(1), 204. https://doi.org/10.17509/jpm.v1i1.3389

Stanton, J. M., Sinar, E. F., Balzer, W. K., Julian, A. L., Thoresen, P., Aziz, S., Fisher, G. G., \& Smith, P. C. (2002). Development of a compact measure of job satisfaction: The abridged Job Descriptive Index. Educational and Psychological Measurement, 62(1), 173-191. https://doi.org/10.1177/001316440206200112

Sunaryo, (2013), Pengaruh Budaya Organisasi dan Pelatihan Terhadap Peningkatan Kinerja Karyawan di PT. Sawit Bandar Durian Medan, Jurnal STIE Harapan Medan.

Suwatno \& Priansa, D. (2011). Manajemen SDM dalam organisasi Publik dan Bisnis. Bandung: Alfabeta

Tobing., Sulianti, Diana K. L., (2009). Pengaruh Komitmen Organisasional dan Kepuasan Kerja Terhadap Kinerja Karyawan PT.Perkebunan Nusantara III di Sumatera Utara, Jurnal Fakultas Ekonomi, Universitas Jember.

Turner, C.H, (1994), Corporate Culture: How to Generate Organisational Strength and Lasting Commercial Advantage. London: Piatkus.

Uha, Ismail Nawawi. (2013). Budaya Organisasi Kepemimpinan \& Kinerja. Jakarta: Kencana.

Usman, Husaini. (2011). Manajemen Teori, praktik dan Riset Pendidikan (Edisi 3.): Jakarta: Bumi Aksara. Wardhani, Arie Puspita., Hasiolan, Leonardo Budi., dan Minarsih, Maria Magdalena (2016). Pengaruh Lingkungan Kerja, Komunikasi Dan Kepemimpinan Terhadap Kinerja Pegawai (Studi kasus di Dinas Kebudayaan dan Pariwisata Kota Semarang), Journal Of Management, Volume 2 No.2 Maret. 